\title{
Produção de sementes sintéticas de maracujazeiro silvestre com potencial ornamental ${ }^{(1)}$
}

\author{
MAURECILNE LEMES DA SILVA(2)*; DANIELA LOPES PAIM PINTO(3); \\ MIGUEL PEDRO GUERRA(4); ELISONETE R. GARCIA LANII(5); ILIO FEALHO DE CARVALHO(2); \\ ANA APARECIDA BANDINI ROSSI(6) e WAGNER CAMPOS OTONI(5)
}

\begin{abstract}
RESUMO
Passiflora cincinnata Mast. é uma espécie silvestre de maracujazeiro de ampla distribuição. Possui hábito trepador e crescimento vigoroso, com flores muito vistosas e perfumadas. O trabalho teve como objetivo a produção de sementes sintéticas da espécie $P$. cincinnata, utilizando-se de embriões somáticos e zigóticos em diferentes formas de cultivo. Os embriões somáticos em estágio de desenvolvimento pré cotiledonar e cotiledonar foram obtidos a partir de embriões zigóticos cultivados em meio de MS na presença de 18,1 $\mu \mathrm{M}$ de 2,4-Ácido-dichlorophenoxiacetico (2,4-D) e 4,5 $\mu \mathrm{M}$ Benziladenine (BA). Embriões zigóticos e embriões somáticos foram encapsulados em matriz de alginato de sódio a 2,5\% ( $\left.\mathrm{pv}^{-1}\right)$ e complexados em solução estéril de $\mathrm{CaCl}_{2} \cdot 2 \mathrm{H}_{2} \mathrm{O}$ a $0,1 \mathrm{M}$. Embriões somáticos e zigóticos foram encapsulados na Matriz(I) com alginato de sódio, Matriz(II) com alginato de sódio + endosperma artificial e Matriz (III) - alginato de sódio + endosperma artificial e suplementado com $0,15 \%\left(\mathrm{p} \mathrm{v}^{-1}\right)$ de carvão ativado. Embriões zigóticos cultivados em frascos encapsulados na Matriz (I) 79\% germinaram, 76\% Matriz (II) e na Matriz (III) $86 \%$. Os embriões somáticos cotiledonares encapsulados nos três tipos de matrizes responderam com maior percentual de germinação quando cultivados em plugs de celulose com mais de $50 \%$ de embriões convertidos. Os embriões somáticos pre cotiledonares encapsulados nos três tipos de matrizes e nas diferentes formas de cultivo não responderam. No cultivo ex vitro nos dois tipos de substratos PlantMax e Florialite o número de embriões convertidos foi baixo, sendo o melhor resultado com 12,67 \% no Florialite e encapsulados na Matriz (I). Palavras-Chave: Passiflora cincinnata, alginato de sódio, sementes artificiais, cultivo in vitro
\end{abstract}

\section{ABSTRACT}

Synthetic seeds of a wild passionfruit species with ornamental potential

Passiflora cincinnata is a wild species of passion fruit with a wide geographical distribution. It has vigorous growth, climbing habit and very showy and fragrant flowers. The aim of the present investigation was to obtain synthetic seeds from encapsulated zygotic and somatic embryos of $P$. cincinnata, cultivated under different conditions. Precotyledonary and cotyledonary stage embryos were obtained from zygotic embryos cultivated on MS medium supplemented with $18.1 \mu \mathrm{M}$ of 2,4-Acid-dichlorophenoxyacetic (2,4-D) and $4.5 \mu \mathrm{M}$ of Benzyladenine (BA). Zygotic embryos and somatic embryos stages were encapsulated using sodium alginate $\left(2.5 \% \mathrm{w} \mathrm{v}^{-1}\right)$ and $\mathrm{CaCl}_{2} 2 \mathrm{H}_{2} \mathrm{O}(1 \mathrm{mM})$ as complexing agent. The zygotic and somatic embryos were encapsulated in a matrix containing (I) sodium alginate, (II) sodium alginate + artificial endosperm and (III) sodium alginate + artificial endosperm supplemented with activated charcoal $(0.15 \% \mathrm{w} / \mathrm{v})$. Zygotic embryos encapsulated in the matrix (I), matrix (II) and matrix (III) and cultivated in flasks, germinated at rates of $79 \%, 76 \%$ and $86 \%$ respectively. The cotyledonary somatic embryos encapsulated in the 3 different matrices showed better germination rates when cultivated on cellulose plugs, with more than $50 \%$ of embryos converted into plants. Precotyledonary somatic embryos did not germinated regardless the matrix and cultivation. When cultivating the alginate beads ex vitro, both substrate Plantmax and Florialite showed low number of germinated embryos, and the best result (12.67\%) were obtained using Florialite and embryos encapsulated in the matrix (I). Keywords: Passiflora cincinnata, sodium alginate, artificial seeds, in vitro culture.

\section{INTRODUÇÃO}

As sementes sintéticas consistem em embrião somático ou qualquer outro tipo de propágulo encapsulado com ou sem endosperma artificial suplementado com nutrientes, substâncias utilizadas no controle de contaminação e ou reguladores de crescimento (GRAY e PUROHIT, 1991;
SILVA et al., 2014). O potencial do uso de sementes sintéticas é amplo, incluindo a facilidade no transporte, armazenamento e plantio de germoplasmas elite e conservação de características clonais, além de proporcionar melhor controle na produção de mudas, tempo de produção e subcultivos reduzidos, sendo que a semeadura pode ser realizada diretamente no campo e baixo custo de produção

\footnotetext{
(1) Recebido em 05/03/2015 e aceito em 03/11/2015.

(2) Universidade do Estado de Mato Grosso (UNEMAT), Tangará da Serra-MT, Brasil. * Autor correspondente: maurecilne@gmail.com

(3) Institute of Life Sciences, Scuola Superiore Sant'Anna, Tuscany, Itália

(4) Universidade Federal de Santa Catarina (UFSC), Departamento de Fitotecnia, Florianópolis-SC, Brasil.

(5) Universidade Federal de Viçosa (UFV), Departamento de Fitotecnia, Viçosa-MG, Brasil.

(6) Universidade do Estado de Mato Grosso (UNEMAT), Departamento de Ciências Biológicas, Alta Floresta-MT, Brasil.
} 
por planta no cultivo in vitro (WEST et al., 2006; SILVA et al., 2014).

A produção de sementes artificiais atualmente tem possibilitado uma nova abordagem na biotecnologia vegetal (NIRANJAN e SUDARSHANA, 2005). Vários são os métodos empregados para a produção de sementes sintéticas. Sendo, o de maior aplicação a gelificação ionotrópica em alginato de sódio por íons de cálcio. $\mathrm{O}$ alginato é um produto de baixo custo, de fácil manuseio e não apresenta toxicidade para a planta. $\mathrm{O}$ encapsulamento de propágulos com alginato de sódio é uma técnica que pode ser utilizada, associada à propagação in vitro para a conservação de inúmeras espécies de plantas (WEST et al., 2006). O uso de sementes artificiais tem sido descrito para várias espécies de plantas ornamentais, cereais, frutíferas, medicinais e lenhosas (GUERRA et al., 2001; NIEVES et al., 2003; WEST et al., 2006; AHMAD e ANIS, 2010; SHARMA et al., 2013; a SILVA et al., 2014).

A importância das passifloráceas decorre da ampla e diversificada utilização pelo homem. Podem ser cultivadas como ornamentais devido à beleza exuberante de suas flores e pela variedade de formatos de suas folhas (CRUZ et al., 2008). Entretanto, no Brasil o mercado dos maracujazeiros como plantas ornamentais é praticamente inexplorado, apesar do enorme potencial que existe como centro de origem de muitas das mais belas espécies. As passifloráceas como plantas ornamentais produzem grande atratividade pela beleza e exuberância de suas flores, com grande variação de coloração forte e brilhante e algumas, outras de coloração tênue e suave (MONTERO et al.; 2013). As flores também são consideradas exóticas e complexas, principalmente pela presença da corona, que caracteriza esta família (ABREU et al., 2009).

Passiflora cincinnata Masters é uma importante espécie silvestre de maracujazeiro, sendo utilizada como portaenxerto compatível para $P$. edulis por apresentar resistência à doença da parte aérea causada pela bactéria Xanthomonas axonopodis f. sp. passiflorae (SÃO JOSÉ, 1994). Possui ampla distribuição, principalmente na América tropical (ZERBINI et al., 2008). No Brasil, ocorre desde norte, sul e ao longo da costa brasileira. $P$. cincinnata é conhecida como maracujá-mochila, maracujá-do-mato ou maracujátubarão, de hábito trepador, perene com aproximadamente 4,5 m de comprimento. Esta espécie de maracujazeiro apresenta excelentes respostas morfogênicas com elevado potencial organogênico e embriogênico (OTONI et al., 2103), e tem sido considerada uma espécie modelo para estudos da morfogênese in vitro do gênero Passiflora (ROCHA et al., 2012). Protocolos responsivos de embriognese somática possuem um grande potencial de aplicação na propagação de maracujazeiros (SILVA et al., 2009; OTONI et al., 2103). A resposta efetiva na germinação dos embriões encapsulados proporciona a perspectiva de sua utilização principalmente para conservação a partir de técnicas de criopreservação. Além disso, possibilita a redução de subcultivos recorrentes in vitro, baixo custo de manutenção de bancos de germoplasma e a manutenção da capacidade germinativa dos propágulos (SILVA et al., 2014).
O trabalho teve como objetivo a produção de sementes sintéticas de Passiflora cincinnata utilizando como fonte de propágulos embriões somáticos e zigóticos em diferentes formas de cultivo.

\section{MATERIAL E MÉTODOS}

\section{Material vegetal e estabelecimento das culturas embriogênicas}

Sementes de $P$. cincinnata após a extração manual do suco foram colocadas para fermentar em sua própria polpa em recipiente plástico à temperatura ambiente, por um período de três dias. Em seguida, as sementes foram friccionadas com areia lavada até que toda mucilagem do arilo fosse retirada e colocadas para secar a sombra por 10 dias. Os tegumentos das sementes foram retirados com o com auxílio de uma mini-morsa. Em seguida, foram desinfestadas em etanol $70 \%\left(\mathrm{v} \mathrm{v}^{-1}\right)$ por 1 minuto, em seguida imersas em hipoclorito de sódio comercial a 2,5\% $\left(\mathrm{v} \mathrm{v}^{-1}\right)$ com 3 gotas de Tween-20 por $100 \mathrm{~mL}$ de solução durante 20 minutos e, submetidas a 4 enxágues em água deionizada e autoclavada. Previamente, ao isolamento dos embriões, as sementes foram mantidas por 3 horas em água deionizada e autoclavada para rehidratação e facilitar a retirada dos embriões zigóticos.

Os embriões zigóticos foram assepticamente removidos e inoculados em meio de indução de embriogênese somática descrito por (SILVA et al., 2009), suplementado com sais básicos de MS (MURASHIGE e SKOOG, 1962), vitamina $\mathrm{B}_{5}$ (GAMBORG et al., 1968), 0,01\% $\left(\mathrm{p} \mathrm{v}^{-1}\right)$ de mio-inositol e $0,3 \%\left(\mathrm{p} \mathrm{v}^{-1}\right)$ de sacarose, $0,28 \%\left(\mathrm{p} \mathrm{v}^{-1}\right)$ de Phytage $^{\circledR}$ como agente gelificante. Os embriões foram cultivados em meio com 18,1 $\mu \mathrm{M}$ de 2,4-D e 4,5 $\mu \mathrm{M}$ de BA como descrito por Silva et al. (2009). O pH do meio foi ajustado para $5.7 \pm 0,1$ e, em seguida, autoclavado por 20 minutos, $121{ }^{\circ} \mathrm{C}$ e $1,1 \mathrm{~atm}$ de pressão. $\mathrm{O}$ meio foi vertido em placas de Petri estéreis de poliestireno cristal de $60 \times 15 \mathrm{~mm}$ em alíquotas de 12 a $15 \mathrm{~mL}$, sendo essas seladas com filme de policloreto de vinila - PVC esticável de 9-10 $\mu \mathrm{m}$ de poro. Foram inoculados 10 embriões zigóticos por placa com 3 repetições. As culturas foram mantidas no escuro durante 30 dias e foram transferidas para meio de histodiferenciação em placas de Petri estéreis de poliestireno cristal de 90 x15 $\mathrm{mm}$, contendo 25 a $30 \mathrm{~mL}$ de meio com os sais básicos de MS, vitamina B5, 0,01\% mio-inositol, sacarose a 3\% $\left(\mathrm{p} \mathrm{v}^{-1}\right)$, carvão ativado $3 \%\left(\mathrm{p} \mathrm{v}^{-1}\right)$, Fitagel ${ }^{\circledR} 0,28 \%\left(\mathrm{p} \mathrm{v}^{-1}\right)$ e seladas com filme de PVC. As culturas foram mantidas em sala de cultivo sob irradiância com fotoperíodo de $16 \mathrm{~h}$ com $36 \mu \mathrm{mol} \mathrm{m}{ }^{-2} \mathrm{~s}^{-1}$ com duas lâmpadas fluorescente (Luz do Dia Especial, 20W, Osram, Brazil) e 8 horas de escuro, com temperatura de $26 \pm 2{ }^{\circ} \mathrm{C}$.

Encapsulamento, cultivo in vitro das sementes sintéticas e germinação dos embriões somáticos

Para o encapsulamento dos embriões utilizou-se o alginato de sódio (Sigma Chemical Company, USA) a 2,5\% $\left(\mathrm{p} \mathrm{v}^{-1}\right)$. As cápsulas foram confeccionadas com o uso de ponteiras $(0,5 \mathrm{~mL})$ com a ponta seccionada para a captura dos embriões embebidos na matriz de alginato de sódio e 
em seguida imersos em solução estéril de $\mathrm{CaCl}_{2} \cdot 2 \mathrm{H}_{2} \mathrm{O}$ a $0,1 \mathrm{M}$, durante 20 minutos para a complexação. Após, as cápsulas foram lavadas em água deionizada e autoclavada, sendo dispostas em papel filtro para a absorção do excesso de água. Embriões somáticos em estágios pré-cotiledonar, cotiledonar e embriões zigóticos maduros (Figura 1B) foram encapsulados nos tratamentos contendo alginato de sódio (Matriz I); alginato de sódio e endosperma artificial suplementado com os sais básicos do meio de MS na metade da concentração (Matriz II); e matriz com alginato de sódio e endosperma artificial suplementado com meio de MS na metade da concentração salina e carvão ativado a $0,15 \%$ (Matriz III). O pH de todos os tratamentos foram ajustado para 5,7 $\pm 0,1$ e autoclavado por $20 \mathrm{~min}$. $\left(121^{\circ} \mathrm{C}\right.$ e $1,1 \mathrm{~atm}$ de pressão). As unidades encapsuláveis foram cultivadas em frascos contendo meio gelificado com ágar Merck $^{\circledR} \mathrm{e}$ água. As condições de cultivo foram à temperatura de $26 \pm$ $2{ }^{\circ} \mathrm{C}$, fotoperíodo de 16 horas de luz e 8 horas de escuro, e irradiância de $36 \mu \mathrm{mol} \mathrm{m} \mathrm{m}^{-1}$ providas por duas lâmpadas fluorescentes (Luz do Dia Especial, 20 W, Osram, Brasil). Todos os experimentos foram submetidos às mesmas condições de cultivo in vitro, assim como a determinação da germinação dos embriões. Para cada tratamento foi considerado uma unidade encapsulável como uma repetição em um total de 10 unidades. Após 30 dias de cultivo in vitro foram avaliados o número de embriões somáticos germinados a partir do rompimento da matriz de alginato de sódio e a emissão dos primórdios radiculares.

\section{Cultivo in vitro das sementes sintéticas em plugs de celulose}

Embriões somáticos em estágio cotiledonar foram cultivados em plugs de celulose Sorbarod ${ }^{\mathrm{TM}}$ nas condições de cultivo, anteriormente descritas. Os embriões encapsulados foram cultivados em frascos e em cada plug de celulose foi cultivado 1 unidade encapsulável, em um total de 5 unidades com 3 repetições. Os plugs de celulose foram umedecidos com água estéril e posteriormente foram inoculadas as unidades encapsuláveis nos tratamentos com a ausência de endosperma artificial e com sais básicos do meio de MS na metade da concentração para as unidades com endosperma artificial.

Cultivo ex vitro das sementes sintéticas em substratos Embriões somáticos em estágio cotiledonar encapsulados foram cultivados em caixas de germinação Gerbox contendo os substratos Plantmax ${ }^{\circledR}$ e Florialite ${ }^{\mathrm{TM}}$, previamente autoclavados por $20 \mathrm{~min}$. $\left(121^{\circ} \mathrm{C}\right.$ e $1,1 \mathrm{~atm}$ de pressão). As sementes artificiais foram dispostas sobre a superfície dos substratos e umedecidas uma vez com aspersão de água destilada e autoclavada a cada 10 dias de cultivo. Foram mantidas à temperatura de $26 \pm 2{ }^{\circ} \mathrm{C}$, sob fotoperíodo de 16 horas de luz e 8 horas de escuro, irradiância de $36 \mu \mathrm{mol} \mathrm{m} \mathrm{m}^{-2} \mathrm{~s}^{-1}$ provido por duas lâmpadas fluorescentes (Luz do Dia Especial, 20 W, Osram, Brasil). Foram cultivadas 10 unidades encapsuláveis por Gerbox, com 3 repetições, sendo avaliado o número de unidades encapsuláveis como embriões somáticos germinados, após 30 dias de cultivo.

\section{Coleta de dados e análise estatística}

Os dados foram avaliados através da freqüência de germinação dos embriões somáticos. Foi realizada a análise de variância (ANOVA) e teste de comparação de médias utilizando o teste de Tukey $(\mathrm{p}<0,05)$. Os experimentos seguiram o delineamento fatorial sendo observado o tipo de matriz no encapsulamento e o tipo de propágulos $(3 \times 3)$ e foram repetidos pelo menos uma vez.

\section{RESULTADOS E DISCUSSÃO}

P. cincinnata é uma espécie potencial para ornamentação com suas flores exuberantes (Figura 1A) e na embriogênese somática é considerada planta modelo do gênero Passiflora. A embriogênese somática em $P$. cincinnata foi obtida a partir de embriões zigóticos isolados de sementes maduras, que responderam com sucesso produzindo embriões somáticos na combinação $18,1 \mu \mathrm{M}$ de 2,4-D e 4,5 $\mu \mathrm{M}$ de BA. As massas pro-embriogênicas apresentaram coloração amarela e aspecto friável, após 30 dias de cultivo. A transferência das massas pro-embriogênicas para o meio de histodiferenciação na ausência dos reguladores de crescimento forneceram condições ideais para o desenvolvimento de grande número de embriões somáticos de forma indireta (Figura 1B). O protocolo de embriogênese somática de $P$. cincinnata estabelecido por Silva et al. (2009) têm sido aplicado para a obtenção de embriões somáticos em várias espécies de Passiflora (PAIM-PINTO et al., 2010; ROCHA et al., 2012; ROSA et al., 2015; FERREIRA et al., 2015).

A germinação dos embriões somáticos e zigóticos encapsulados utilizados como fonte de propágulos teve inicio aos 10 dias de cultivo in vitro (Figura1C). A utilização de alginato de sódio a $2,5 \%$ em presença de $\mathrm{CaCl}_{2} \cdot 2 \mathrm{H}_{2} \mathrm{O}$ (1 $\mathrm{mM})$ resultou na polimerização de cápsulas estáveis e definidas de hidrogel (Figuras 1D-E). As unidades encapsuláveis com os embriões zigóticos, cultivados em frascos (Figura 1F) somente com a matriz I constituída de alginato de sódio resultaram em 79\% de germinação com o desenvolvimento e alongamento da radícula e (Figura 2) e o desenvolvimento dos primórdios foliares. As unidades com o endosperma artificial constituído dos sais básicos de MS (Matriz II) 76\% e na Matriz III com endosperma artificial + carvão ativado 86\% (Figura $1 \mathrm{G}$ ) dos embriões converteram em plântulas. Diferenças estatísticas não foram observadas entre os tratamentos (Figura 2). 


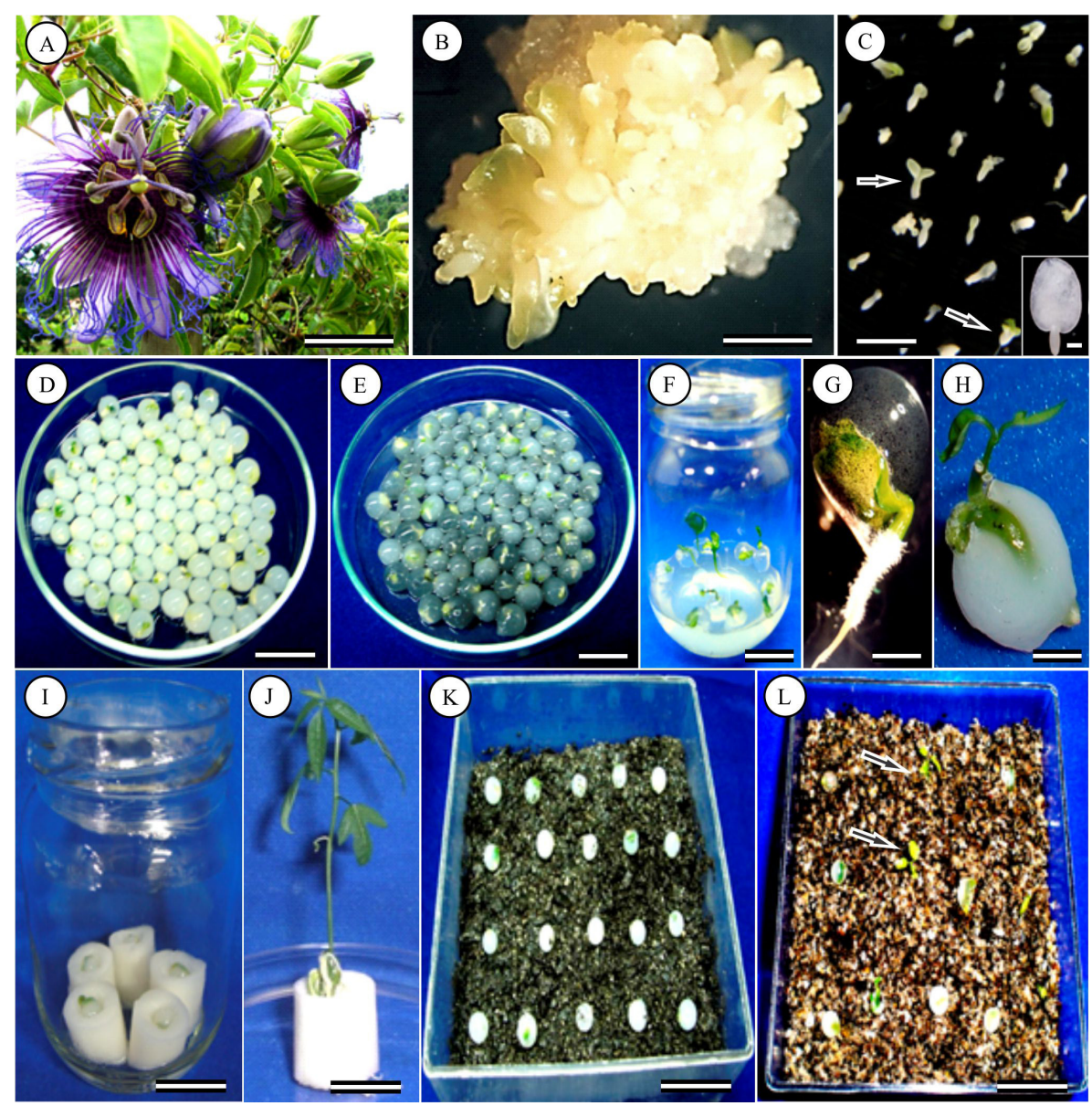

Figura 1. Produção de sementes sintéticas de Passiflora cincinnata Mast. (A) - Flor de P. cincinnata. (B) - Cluster de embriões somáticos em diferentes fases de desenvolvimento. Bar $=150 \mu \mathrm{m}$. (C) - Embriões somáticos em estágios pré-cotiledonar, cotiledonar (Bar $165 \mu \mathrm{m}$ ) e em detalhe embrião zigótico. (Bar $2 \mathrm{~mm}$ ). (D-E) - Embriões somáticos encapsulados na matriz I com alginato de sódio e s matriz II com alginato e endosperma artificial com carvão ativado (Bar $82 \mathrm{~mm}$ ). (F) - Germinação de sementes sintéticas a partir de embriões zigóticos maduros cultivadas em frascos (Bar $58 \mathrm{~mm}$ ). (G) - Germinação embriões zigóticos encapsulados na Matriz (II) com alginato de sódio suplementado

com meio de MS1122 e carvão ativado/endosperma artificial (Bar $50 \mu \mathrm{m}$ ); (H) - Germinação de embrião somático cotiledonar encapsulado na Matriz I - alginato de sódio (Bar $50 \mu \mathrm{m})$. (I) - Embriões somáticos encapsulados cultivados em frascos em plugs de celulose (Bar $58 \mathrm{~mm}$ ). (J) - Plântula convertida a partir de embrião somático cultivada em plug de celulose. (Bar $55 \mathrm{~mm}$ ). (K) - Sementes sintéticas cultivadas em condição ex vitro em Gerbox com substrato Plantmax ${ }^{\circledR}($ Bar $60 \mathrm{~mm})$. (L) - Sementes sintéticas cultivadas ex vitro em Gerbox com substrato e Florialite ${ }^{\mathrm{TM}}$. As setas indicam a conversão dos embriões encapsulados em plântulas (Bar $60 \mathrm{~mm}$ ).

Figure 1. Production of synthetic seeds from zygotic and somatic embryos of P. cincinnata Mast. (A) - P. cincinnata flower. (B) - Clusters of embryos at different developmental stages. Bar $=150 \mu \mathrm{m} .(C)$ - Somatic embryos at precotyledonary and cotyledonary stages and in detail the zygotic embryo. Bars $=165 \mu \mathrm{m}$ and $2 \mathrm{~mm}$. (D-E) - Somatic embryos encapsulated in the matrix I with sodium alginate and matrix II with alginate and endosperm with activated charcoal. (Bar $82 \mathrm{~mm}$ ). (F) - Synthetic seeds germination from mature zygotic embryos incubated in flasks (Bar 58 mm). (G) - Germination of zygotic embryos encapsulated in calcium alginate matrix (Bar $50 \mu m$ ). (H) - Germination of cotyledonary somatic embryo encapsulated in calcium alginate matrix I (Bar $50 \mu \mathrm{m})$. (I) - Encapsulated somatic embryos incubated in cellulose plugs (Bar $58 \mathrm{~mm}$ ). (J)- Plantlets derived from somatic embryos cultivated in cellulose plug (Bar $55 \mathrm{~mm}$ ). (K) - Synthetic seeds cultivated ex vitro in Gerbox containing the substrate Plantmax ${ }^{\circledR}$ (Bar 60 mm). (L) - Synthetic seeds cultivated ex vitro in Gerbox containing the substrate Plantmax and Florialite ${ }^{\circledR}$. The arrows indicate the conversion of encapsulated embryos into plantlets (Bar $60 \mathrm{~mm}$ ). 
Os embriões somáticos em estágio pré cotiledonar encapsulados não germinaram. Já os embriões encapsulados no estágio cotiledonar cultivados em frascos romperam a matriz de alginato de sódio (Figura 1H) com a expansão dos primórdios foliares e o desenvolvimento da radícula. Na Figura 2 podese observar o percentual de germinação dos embriões somáticos cotiledonares para Matriz I foi de $60 \%$, sendo para as matrizes II e III, $50 \%$ e $33 \%$, respectivamente. Os embriões somáticos encapsulados somente na matriz com alginato de sódio obtiveram maior percentual de germinação, podendo o protocolo ser aplicado na produção de sementes sintéticas para $P$. cincinnata e a possibilidade de transferência para outras espécies de Passiflora, como forma de propagação e de conservação através da criopreservação.

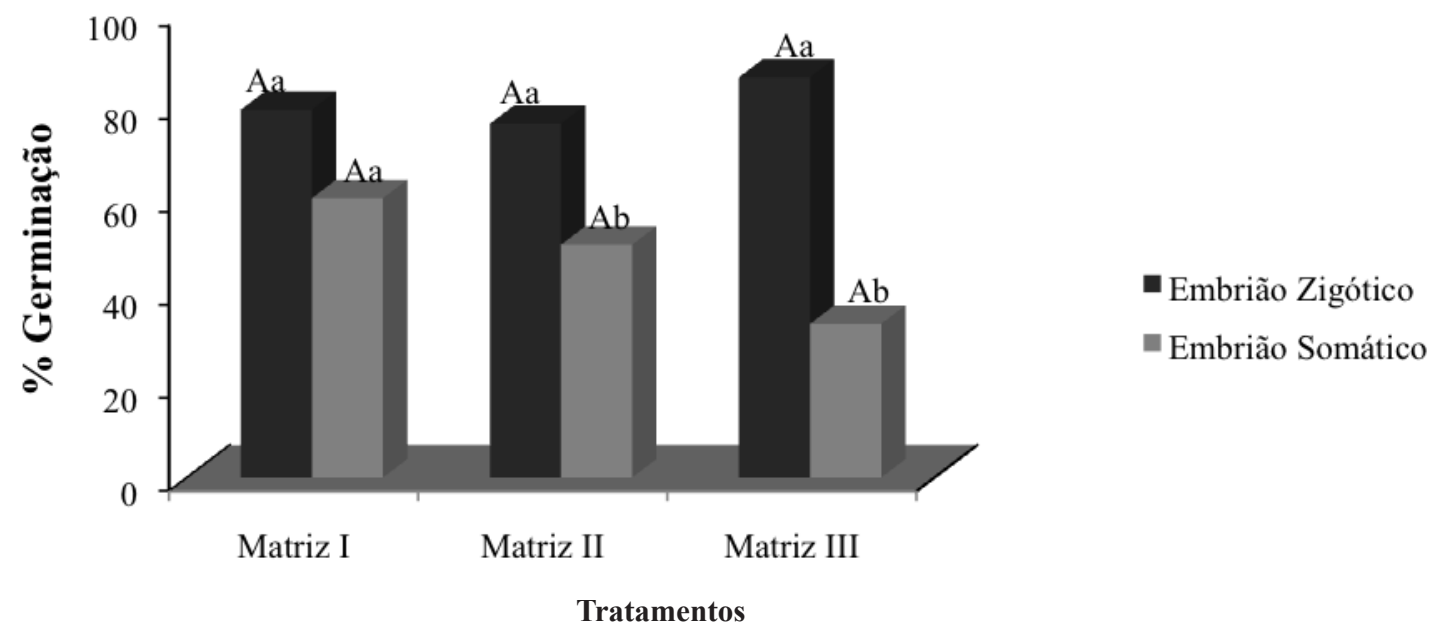

Figura 2. Germinação das sementes sintéticas a partir de embriões zigóticos de $P$. cincinnata cultivados em fracos in vitro. (I) - Embriões zigóticos encapsulados na presença de alginato de sódio 2,5\% (p v $\left.{ }^{-1}\right)$; (II) - Embriões zigóticos encapsulados com endosperma artificial; (III) - Embriões zigóticos encapsulados com endosperma artificial e suplementado com $0,15 \%\left(\mathrm{p} \mathrm{v}^{-1}\right)$ de carvão ativado. Letras maiúsculas comparam o tipo de matriz e as minúsculas o tipo de explantes. As médias seguidas pelas mesmas letras não diferem estatisticamente pelo teste de Tukey $(\mathrm{p}<0,05)$ dentro de cada tratamento envolvendo a germinação das sementes sintéticas.

Figure 2. Germination of synthetic seeds from the zygotic embryos of a P. cincinnata in flasks cultivated in vitro. Encapsulated of zygotic embryos in the presence sodium alginate of a $2.5 \%(w / v)$. Encapsulated of zygotic embryos with artificial endosperm. (II) - Encapsulated of zygotic embryos with artificial endosperm and supplemented with activated charcoal with $0.15 \%(w / v)$. Means followed by the same letter are not statistically significant by Tukey test $(P<0.05)$.

Cangahuala-Inocente et al. (2007) relatam que para a espécie Acca sellowiana a adição dos sais do meio de MS nas cápsulas de alginato de sódio, constituindo endosperma artificial, possibilitou ao embrião somático encapsulado uma maneira de reconstituir parte do endosperma natural da semente como estratégia de aumentar a taxa de conversão em plântulas. Os embriões somáticos em estágio cotiledonar de $P$. cincinnata, aparentemente, já possuem demanda de nutrientes suficientes para esta fase de desenvolvimento e não necessitam da reconstituição do endosperma artificial.

Sementes sintéticas com embriões somáticos em estágio cotiledonar cultivados nos plugs de celulose (Figuras 1I-J), na matriz I apresentou um percentual de $76 \%$, diferindo estatisticamente dos demais tratamentos, sendo 56\% e $64 \%$ para as matrizes II e III sementes sintéticas com endosperma artificial e endosperma mais a adição de carvão ativo (Figura 3). Já nos plugs de celulose umedecidos com meio de $\mathrm{MS}^{1} \frac{2}{2}$, cerca de $40 \%$ dos embriões somáticos encapsulados mantiveram a competência morfogênica na produção de embriogênese repetitiva ou massa celular proembriogênica. Os embriões repetitivos desenvolveramse principalmente na região dos cotilédones. Relato da manutenção da competência embriogênica repetitiva em unidades encapsuláveis cultivadas in vitro foi descrita por Janeiro et al. (1997) com a espécie Camelia japonica, em que nas unidades encapsuláveis compostas pela matriz de alginato de sódio e outra suplementada com meio MS a competência embriogênica foi mantida após 10 semanas de cultivo in vitro. Entretanto, essa competência decaiu em decorrência do armazenamento a baixas temperaturas. 


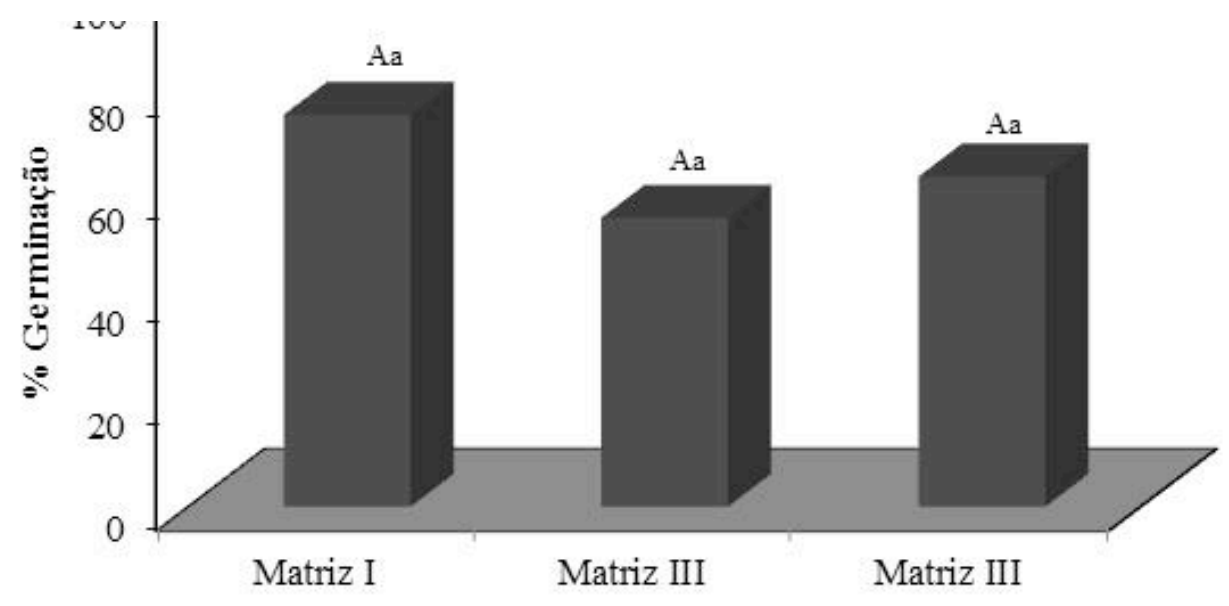

Tratamentos

Figura 3. Germinação de sementes sintéticas a partir de embriões somáticos em estágio cotiledonar de $P$. cincinnata cultivados in vitro em plugs de celulose. (I) - Embriões somáticos encapsulados na presença de alginato de sódio 2,5\% ( $\left.\mathrm{p} \mathrm{v}^{-1}\right)$; (II) - Embriões somáticos encapsulados com endosperma artificial; (III) - Embriões somáticos encapsulados com endosperma artificial e suplementado com $0,15 \%$ de carvão ativado. Letras maiúsculas comparam o tipo de matriz e as minúsculas o tipo de explantes. As médias seguidas pelas mesmas letras não são estatisticamente significativas pelo teste de Tukey $(\mathrm{p}<0,05)$, dentro de cada tratamento envolvendo a germinação das sementes sintéticas.

Figure 3. Germination of synthetic seeds from the somatic embryos at cotyledonary stage of a P. cincinnata cultivated plugs de cellulose in vitro. (I) - Encapsulated of zygotic embryos in the presence sodium alginate of a $2.5 \%$ (w/v). (II) - Encapsulated of somatic embryos with artificial endosperm. (II)-Encapsulated of somatic embryos with artificial endosperm and supplemented with activated charcoal with $0.15 \%(w / v)$. Means followed by the same letter are not statistically significant by Tukey test $(P<0.05)$.

Em relação ao cultivo ex vitro embriões somáticos em estágio cotiledonar cultivados com os substratos Plantmax ${ }^{\circledR}$ (Figura $1 \mathrm{~K}$ ) e Florialite ${ }^{\mathrm{TM}}$ (Figura $1 \mathrm{~L}$ ) a maior taxa de germinação de $12,67 \%$ obtida em resposta ao substrato Florialite $^{\mathrm{TM}}$ (Figura 1K) na Matriz (I) e 6\% no substrato Plantmax. Já os embriões encapsulados na Matriz (II) com endosperma artificial resultaram em $1,33 \%$ de embriões germinados em substrato Plantmax ${ }^{\circledR}$ e 7,33\% em Florialite $^{\mathrm{TM}}$ (Figura 3), e os na Matriz (III) suplementados com carvão ativado $2,67 \%$ em Plantmax $^{\circledR}$ e 6,67\% em Florialite ${ }^{\mathrm{TM}}$. Aparentemente, o maior número de embriões germinados cultivados no substrato Florialite ${ }^{\mathrm{TM}}$, deve-se a sua capacidade de aeração no ambiente de cultivo. Esse substrato tem sido largamente utilizado como sistema de suporte na propagação fotoautotrófica (SALDANHA et al., 2014), consistindo numa mistura de polpa de celulose e vermiculita (83:17).
No cultivo de sementes sintéticas de $P$. cincinnata sob as condições in vitro e ex vitro, em todos os tratamentos foram obtidos resultados semelhantes quanto aos embriões somáticos encapsulados somente na matriz de alginato de sódio, apresentando maior índice de germinação e conversão de plantas com desenvolvimento normal. Entretanto, ainda são necessários testes de armazenamento à baixa temperatura para maior viabilidade na utilização da técnica, bem como, a intensificação de estudos relacionados ao plantio das sementes sintéticas em casa de vegetação e no campo em escala comercial. Outros fatores a serem considerados são o aprimoramento no sistema de obtenção dos embriões somáticos de forma mais sincronizada, com a possibilidade de utilização de biorreatores e estender o sistema embriogenético para outras espécies de Passiflora. 


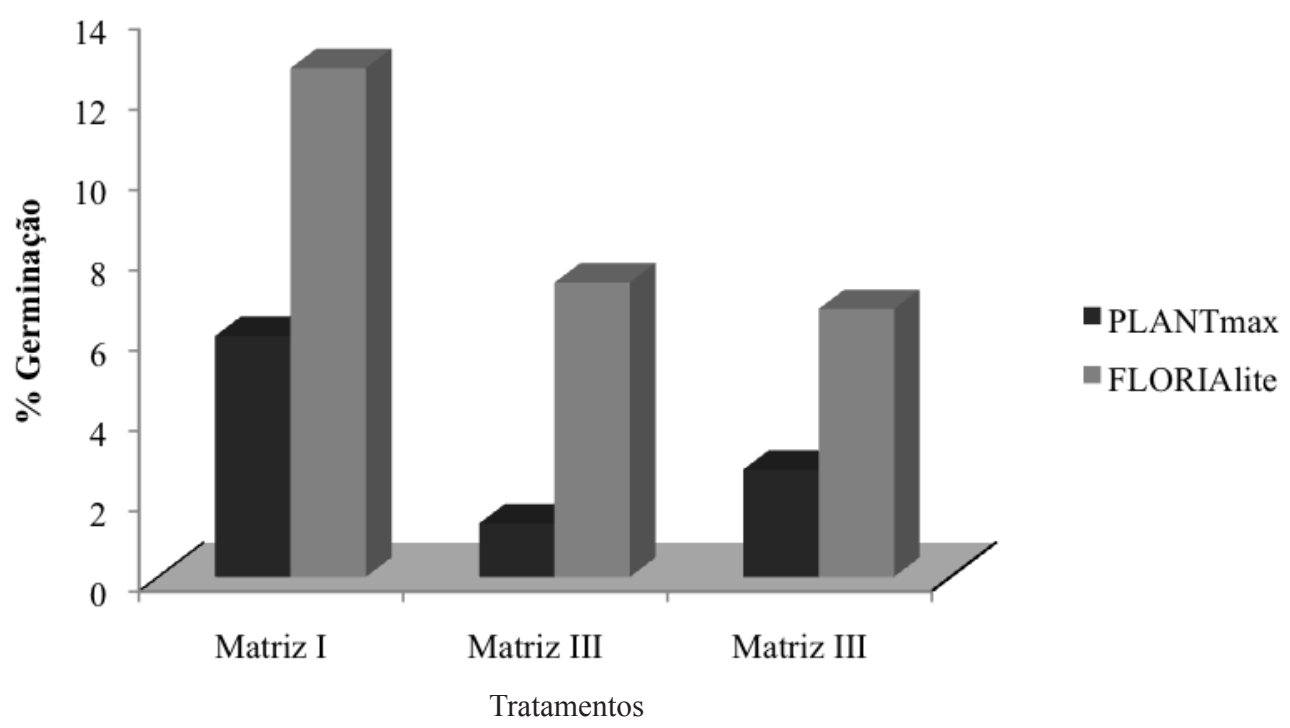

Figura 4. Germinação das sementes sintéticas a partir de embriões somáticos em estágio cotiledonar de $P$. cincinnata cultivados ex vitro em substratos Plantmax $^{\circledR}$ e Florialite ${ }^{\mathrm{TM}}$ (I) - Embriões somáticos encapsulados na presença de alginato de sódio 2,5\% ( $\left.\mathrm{p} \mathrm{v}^{-1}\right)$; (II) - Embriões somáticos encapsulados com endosperma artificial; (III) -

Embriões somáticos encapsulados com endosperma artificial, suplementado com $0.15 \%$ de carvão ativado.

Figure 4. Germination of synthetic seeds from the somatic embryos at cotyledonary stage of a P. cincinnata cultivaded in substrates Plantmax ${ }^{\circledR}$ e Florialite ${ }^{\mathrm{TM}}$ ex vitro. (I) - Encapsulated of zygotic embryos in the presence sodium alginate of a $2.5 \%\left(\mathrm{w} \mathrm{v}^{-1}\right)$. (II) - Encapsulated of somatic embryos with artificial endosperm. (II) - Encapsulated of somatic embryos with artificial endosperm and supplemented with activated charcoal with $0.15 \%\left(\mathrm{w} \mathrm{v}^{-1}\right)$.

\section{CONCLUSÕES}

Os embriões zigóticos e somáticos em estágio de desenvolvimento cotiledonar responderam positivamente como fonte de propágulos para a produção das unidades encapsuláveis de $P$. cincinnata. A utilização de plugs de celulose pode ser uma alternativa como substrato para o cultivo de sementes sintéticas, até a obtenção da plântula que pode ser cultivada fora das condições do ambiente in vitro. No cultivo dos embriões somáticas em condições ex vitro recomenda-se a utilização do substrato FlorialiteTM .

\section{REFERÊNCIAS}

ABREU, P.P. Passion flower hybrids and their use in the ornamental plant market: perspectives for sustainable development with emphasis on Brazil. Euphytica, Wagenigen, v.166, n.3, p.307-315, 2009.

AHMAD, N.; ANIS, M. Direct plant regeneration from encapsulated nodal segments of Vitex negundo. Biologia Plantarum, Dordrecht, v.54, n.4, p.748-752, 2010. DOI: 10.1007/s10535-010-0134-8.

CANGAHUALA-INOCENTE, G.C; DAL VESCO, L.L.; STEINMACHER, D.; TORRES. A.C.; GUERRA, M.P. Improvements in somatic embryogenesis protocol in Feijoa (Acca sellowiana (Beg) Burret): Induction, conversion and synthetic seeds. Scientia Horticulturae, Amsterdam, v.111, n.3, p.228-234, 2007. DOI: 10.1016/j. scienta.2006.10.030
CRUZ, T.V.; SOUZA, M.M.; ROZA, F.A.; VIANA, A.J.C.; BELO, G.O.; FONSECA, J.W.S. Germinação in vitro de grãos de pólen em Passiflora suberosa $\mathrm{L}$. para sua utilização em hibridação interespecífica. Revista Brasileira de Fruticultura, Jaboticabal, v.30, n.4, p.875-879, 2008. DOI: 10.1590/S010029452008000400006 .

FERREIRA, D.A.T.; SATTLER, M.C.; CARVALHO, C.R.; CLARINDO, W.R. Embryogenic potential of immature zygotic embryos of Passiflora: a new advance for in vitro propagation without plant growth regulators. Plant Cell, Tissue and Organ Culture, Dordrecht, p.1-10. DOI: 1007/s11240-015-0796-1.

GAMBORG, O.L.; MILLER, R.A.; OJIMA, K. Nutrient requirement of suspension cultures of soybean root cells. Experimental Cell Research, San Diego, v.50, n.1, p.151158, 1968. DOI: 10.1016/0014-4827(68)90403-5.

GRAY, D.J; PUROHIT, A. Somatic embryogenesis and development of synthetic seed technology. Plant Science, Chicago, v.10, n.1, p.33-61, 1991. DOI: 10.1080/07352689109382306.

GUERRA, M.P.; DAL VESCO, L.; DUCROQUET J. P.H.J.; NODARI, R.O.; REIS, M.S. Somatic embryogenesis in goiabeira serrana: genotype response, auxinic shock and synthetic seeds. Revista Brasileira de Fisiologia Vegetal, Lavras, v.13, n.2, p.117-128, 2001. DOI: http://dx.doi. org/10.1590/S0103-31312001000200001 
JANEIRO, L.V.; BALLESTER, A.; VIEITEZ, A.M. In vitro response of encapsulated somatic embryos of camellia. Plant Cell, Tissue and Organ Culture, Dordrecht, v.51, n.2, p.119-125, 1997. DOI: 10.1023/A:1005958827202.

MONTERO, D.A.V.; MELETTI, L.MA. M.; MARQUES; MAYO, M.O. Fenologia do florescimento e características do perfume das flores de Passiflora quadrangularis 1. (maracujá-melão). Revista Brasileira de Horticultura Ornamental, Campinas, v.19, n.2, p.99-106, 2013. DOI: http://dx.doi.org/10.14295/rbho.v19i2.654.

MURASHIGE, T.; SKOOG, F. A revised medium for rapid growth and bioassays with tobacco tissue cultures. Physiologia Plantarum, Madison, v.15, n.3, p.473-497, 1962. DOI: 10.1111/j.1399-3054.1962.tb08052.x.

NIEVES, N.; ZAMBRANO, Y.; TAPIA, R.; CID, M.; PINA, D.; CASTILLO, R. Field performance of artificial seed-derived sugarcane plants. Plant Cell, Tissue and Organ Culture, Dordrecht, v.75, n.3, p.279-282, 2003. DOI: 10.1023/A:1025855611981.

NIRANJAN M.H.; SUDARSHANA M.S. In vitro response of encapsulated somatic embryos of Lagerstroemia indica L. Indian Journal Experimental Biology, New Delhi, n.43, v.6, p.552-554, 2005.

OTONI, W.C.; PAIM-PINTO, D.L.; ROCHA, D.I.; VIEIRA, L.M.; DIAS, L.L.C.; SILVA, M.L.; SILVA, C.V.; LANI, E.R.G.; SILVA, L.C.D.; TANAKA, F.A.O. Organogenesis and Embryogenesis in Passionfruit (Passiflora sps.). In: ASLAM; J.; SRIVASTAVA; P.S.; SHARMA, M.P. (eds) Somatic Embryogenesis and Gene Expression. New Delhi: Narosa Publishing House, 2013. p.1-17.

PAIM PINTO, D.L., BARROS, B.A., VICCINI, L.F., CAMPOS, J.M.S., SILVA, M.L., OTONI, W.C. Ploidy stability of somatic embryogenesis-derived Passiflora cincinnata Mast. plants as assessed by flow cytometry. Plant Cell Tissue and Organ Culture, Dordebrecht, v.103, p.71-79, 2011. DOI: 10.1007/s11240-010-9756-y

PAIM PINTO, D.L., ALMEIDA, A.M.R., RÊGO, M.M., SILVA, M.L., OLIVEIRA, E.J., OTONI, W.C. Somatic embryogenesis from mature zygotic embryos of commercial passionfruit (Passiflora edulis Sims) genotypes. Plant Cell Tissue and Organ Culture, Dordebrecht, v.107, n.3, p.521-530, 2011. DOI: 10.1007/s11240-011-0003-y

REDENBAUGH, K. Synseeds: Applications of Synthetic Seeds to Crop Improvement, Boca Raton: CRC Press, 1993. 481p.

ROCHA, D.I.; VIEIRA, L.M.; TANAKA, F.A.; DA SILVA, L.C.; OTONI, W.C. Somatic embryogenesis of a wild passion fruit species Passiflora cincinnata Masters: histocytological and histochemical evidences.
Protoplasma, Vienna, v.249, p.747-758, 2012. DOI: 10.1007/s00709-011-0318-x

ROSA, Y.B.C.J.; BELLO, C.C.M.; DORNELAS, M.C. Species-dependent divergent responses to in vitro somatic embryo induction in Passiflora spp. Plant Cell Tissue and Organ Culture, Dordebrecht, v.120, p.69-77, 2014.

SAKAR, D.; NAIK, P.S. Synseeds in potato: an investigation using nutrient-encapsulated in vitro nodal segments. Scientia Horticulturae, New York, v.73, n.2-3, p.179-184, 1998. DOI: 10.1016/S0304-4238(97)00146-5

SALDANHA, C.W.; OTONI, C.G.; ROCHA, D.I.; CAVATTE, P.C.; DETMANN, K.S.C.; TANAKA, F.A.O.; DIAS, L.L.C.; DAMATTA F.M.; OTONI, W.C. $\mathrm{CO}_{2}-$ enriched atmosphere and supporting material impact the growth, morphophysiology and ultrastructure of in vitro Brazilian-ginseng [Pfaffia glomerata (Spreng.). Pedersen] plantlets. Plant Cell Tissue and Organ Culture, Dordrecht, v.118, p.87-99, 2014. DOI 10.1007/s11627-014-9651-z

SÃO JOSÉ, A.R. Maracujá: produção e mercado. Vitória da Conquista: UESB, 1994. 255p.

SHARMA, S.; SHAHZAD, A.; TEIXEIRA da SILVA, J. A. Synseed technology - Acomplete synthesis. Biotechnology Advances, New York, v.31, n.2, p.186-207, 2013. DOI:10.1016/j.biotechadv.2012.09.007

SILVA, J.A.; ZENG, S.; GALDIANO Jr., R.F.; DOBRÁNSZKI, J.; CARDOSO, J.C.; VENDRAME, W.A. In vitro conservation of Dendrobium germplasm. Plant Cell Reports, Berlin, v.33, n.9, p.1413-1423, 2014.

SILVA M.L., PAIM PINTO, D.L., GUERRA, M.P., FLOH, E.I.S., BRUCKNER, C.H., OTONI, W.C. A novel regeneration system for a wild passion fruit species (Passiflora cincinnata Mast.) based on somatic embryogenesis from mature zygotic embryos. Plant Cell Tissue and Organ Culture, Dordrecht, n.99, p. 47-54, 2009.

STANDARDI, A.; PICCIONI, E. Recent perspectives on the synthetic seed techonology using non-embryogenic vitro-derived explants. International Journal of Plant Sciences, v.159, n.6, p.968-978, 1998. DOI: http://www. jstor.org/stable/10.1086/314087

WEST, T.P; RAVINDRA, M. B.; PREECE, J.E. Encapsulation, cold storage, and growth of Hibiscus moscheutos nodal segments. Plant Cell, Tissue and Organ Culture, Dordrecht, v.87, n.3, p.223-231, 2006. DOI: $10.1007 / \mathrm{s} 11240-006-9155-6$

ZERBINI, F.M., OTONI, W.C., VIEIRA, M.L.C. Passionfruit. In: KOLE, C.; HALL, T. C. A Compendium of Transgenic Crop Plants: Tropical and Subtropical Fruit and Nuts. Berlin: John Wiley \& Sons, 2008. p. 213234. 